\title{
Growth Of Financial Performance PT. Gresik Cipta Sejahtera (GCS) Year 2011-2014 Using Financial Ratio Analysis
}

\author{
Boni A Pasaribu \\ Department of Commerce/Business Administration Science, University Of North Sumatra, Indonesia.
}

\begin{tabular}{|c|c|}
\hline ARTICLE INFO & ABSTRACT \\
\hline Article history: & \multirow{4}{*}{$\begin{array}{l}\text { Assessment of financial performance can be known through a } \\
\text { report, a report which describes the growth of the company's } \\
\text { financial performance in certain periods. The report is called the } \\
\text { financial statements. In order to make the financial statements useful } \\
\text { for the parties concerned, it is needed to conduct analysis of the } \\
\text { relations of the items in the financial statements which is often called } \\
\text { financial statement analysis. The purpose of this study, to determine } \\
\text { the growth of financial performance at PT. Gresik Cipta Sejahtera } \\
\text { Medan in } 2011-2014 \text { based on the analysis of liquidity, leverage, and } \\
\text { profitability. The data analysis method used is comparative } \\
\text { descriptive method using a ratio measurement of liquidity, leverage, } \\
\text { and profitability. Based on the current ratio, inventory to net working } \\
\text { capital and debt to equity ratio, the company is in good shape, } \\
\text { although they fluctuate during the period from } 2011-2014 \text {. Based on } \\
\text { the quick ratio, cash ratio, debt ratio, gross profit margin, net profit } \\
\text { margin, ROI, and ROE, the company is in unfavorable } \\
\text { circumstances, thus encouraged to improve efficiency. }\end{array}$} \\
\hline $\begin{array}{r}\text { Received Mei 01, } 2021 \\
\text { Revised Jun 05, } 2021 \\
\text { Accepted Jul 30, } 2021\end{array}$ & \\
\hline & \\
\hline $\begin{array}{r}\text { Financial Statements } \\
\text { Financial Ratios } \\
\text { Financial Performance }\end{array}$ & \\
\hline
\end{tabular}

This is an open access article under the CC BY-NC license.

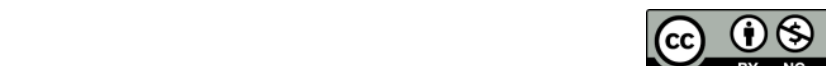

\section{Corresponding Author:}

Boni A Pasaribu,

Department of Commerce/Business Administration Science,

University Of North Sumatra, Indonesia,

Jl. Dr. Mansur No. 9 Padang Bulan, Kec. Medan Baru, Kota Medan 20222.

Email: bonipasaribu@gmail.com

\section{INTRODUCTION}

Financial statements are an important part of operational activities, especially in corporate finance. The financial statements are prepared based on all the company's financial activities in an accounting period of the company. Later the financial statements will be recorded in the form of balance sheets, income statements and reports of changes in capital. These three are the basis in making a financial report.

Financial statements are prepared for various purposes. Each company must have its own goals that distinguish it from other companies. However, the most common reason for a company to record financial statements is to measure how the company's performance has been during an accounting period. These things will later be used as material to assess whether the company's financial performance has met expectations or not. One technique to measure the company's financial performance is to perform a ratio analysis of the financial statements.

This analysis is called financial statement analysis. In this study, there are 3 types of ratios, namely, Liquidity Ratio, Solvency Ratio (Leverage Ratio), and Profitability Ratio (Profitability Ratio). By using this analysis for each accounting period, it will be known how the growth of a company's 
performance. These ratios will later be used by the author in his research at PT. Gresik Cipta Sejahtera Medan Branch.

As a company that has been established since 1972, PT. Gresik Cipta Sejahtera has made many decisions to achieve the targets previously made by the company's management. PT. Gresik Cipta Sejahtera was established on June 15, 1972 and is a subsidiary of PT Petrokimia Gresik Group, whose shares are owned by the Petrokimia Gresik Foundation (YPG) and the Petrokimia Gresik Family Employee Cooperative (K3PG).

In recent years, the company claims its company performance has increased. This refers to the sales turnover chart from 2007-2011, where there was growth except in 2009. However, based on the calculations made by the company, they believe they are still in a position that has the opportunity to continue to grow at times. will come.

The turnover calculation can be a simple help to see how a company's performance grows from year to year. However, the rise and fall of turnover does not necessarily describe an accurate efficiency. Therefore, the authors want to calculate financial performance by using the analysis of liquidity ratios, solvency ratios, and company profitability ratios for the years 2011-2014. The calculation results can help internal and external parties to make decisions about the company. Financial Ratio Analysis will also help the author to show how the growth of financial performance that occurs in PT. Gresik Cipta Sejahtera from 2011-2014.

\section{RESEARCH METHOD}

This type of research is a comparative descriptive research, by doing a comparison (comparison) the performance of the company PT. Gresik Cipta Sejahtera Medan Branch from 2011-2014 using financial ratio analysis including profitability, liquidity, and solvency ratios. In analyzing information and data, the following techniques are used: Comparative descriptive analysis technique, which is a technique used to describe financial ratio data from observations and then make comparisons between periods for several consecutive years, to determine the growth of financial performance.

\section{RESULTS AND DISCUSSIONS}

\subsection{Data Presentation}

All detailed data comes from the financial statements of PT. Gresik Cipta Sejahtera Medan Branch. The company's financial statements are presented in comparative form for the years 20112014 and can be seen on the display. Writing on the balance sheet starts from the main account then is translated down according to the types of accounts included in the main account. Presentation of the financial statements of PT. Gresik Cipta Sejahtera Medan Branch on views 1 we can see on the next page.

Table 1 . PT. Gresik Copyright Medan Branch Balance December 31, 2011, 2012, 2013, and 2014

\begin{tabular}{ccccc}
\hline & \multicolumn{4}{c}{ In million rupiah } \\
& $\mathbf{2 0 1 1}$ & $\mathbf{2 0 1 2}$ & $\mathbf{2 0 1 3}$ & $\mathbf{2 0 1 4}$ \\
\hline ASSET & $\mathbf{5 , 8 8 1 , 1 0 8}$ & $\mathbf{6 , 5 6 9 , 8 0 7}$ & $\mathbf{6 , 1 3 0 , 3 2 0}$ & $\mathbf{7 , 8 8 3 , 2 9 4}$ \\
Current assets & $\mathbf{4 , 0 6 2 , 2 8 7}$ & $\mathbf{4 , 5 8 4 , 7 0 4}$ & $\mathbf{3 , 9 5 8 , 9 7 7}$ & $\mathbf{5 , 3 6 0 , 6 6 4}$ \\
Cash and cash equivalents & 841.121 & 659,584 & 670,411 & 613,698 \\
Accounts receivable & 865,844 & 505,326 & 470.560 & 1.055 .178 \\
Other receivables & 28,637 & 30854 & 27,617 & 21,673 \\
Stock & $1,802,707$ & $2,447,376$ & $1,617,389$ & $2,461,256$ \\
prepaid taxes & 470.562 & 888,637 & $1,061,151$ & 820,600 \\
Other financial assets & 4.788 & 8,461 & 11,948 & 1,404 \\
Other current assets & 48,628 & 44,466 & 99,901 & 121,700 \\
Assets held for sale & - & - & 265,155 \\
Non-current assets & $\mathbf{1 , 8 1 8 , 8 2 1}$ & $\mathbf{1 , 9 8 5 . 1 0 3}$ & $\mathbf{2 , 1 7 1 , 3 4 3}$ & $\mathbf{2 , 5 2 2 , 6 3 0}$ \\
Other receivables & 50.004 & 48,100 & 52.167 & 90,524 \\
Investment in associates & 134,184 & 127,440 & 100,298 & 131.975 \\
Fixed assets & $1,361,918$ & $1,515,559$ & $1,722,798$ & $1,888,603$ \\
Investment property & 239,062 & 195.165 & 172.725 & 159,374 \\
\hline
\end{tabular}




\begin{tabular}{ccccc}
\hline prepaid taxes & - & - & - & 32,559 \\
Deferred tax assets & 50,758 & 50,134 & 46,833 & 118.908 \\
Other non-current assets & 62.583 & 71.145 & 54,082 & 20,999 \\
LIABILITY & $\mathbf{1 , 6 7 8 , 0 3 3}$ & $\mathbf{1 . 9 7 2 . 0 1 2}$ & $\mathbf{1 . 5 7 2 . 1 2 0}$ & $\mathbf{2 , 9 9 1 , \mathbf { 1 8 4 }}$ \\
Short-term liabilities & $\mathbf{1 , 2 6 9 , 4 8 2}$ & $\mathbf{1 , 4 2 1 , 9 7 6}$ & $\mathbf{9 8 9 , 1 1 9}$ & $\mathbf{2 , 4 3 9 , 5 9 0}$ \\
Accounts payable & 220,734 & 302,358 & 337,115 & 405.533 \\
Short term bank loan & $1,354,762$ & 263.605 & 263.605 & $1,354,762$ \\
Tax debt & 95.613 & 69.304 & 24,468 & 157,742 \\
royalty debt & 14.060 & 19,778 & 17.002 & 3.185 \\
Accrued expenses & 430.677 & 342.079 & 299,901 & 417,908 \\
Other short-term liabilities & 6,844 & 8,747 & 10,969 & 17.011 \\
Liabilities directly related to assets held for sale & 68,867 & 35,067 & 35,067 & 82,417 \\
Long term liabilities & $\mathbf{4 0 8 , 5 5 1}$ & $\mathbf{5 5 0 , 0 3 6}$ & $\mathbf{5 8 3 , 0 0 1}$ & $\mathbf{5 5 1 . 5 9 4}$ \\
Deferred tax liability & 2,548 & 3.361 & 1.069 & 396 \\
Post-employment benefit obligation & 274.945 & 290.769 & 304,362 & 325,092 \\
Long term liabilities other & 131.058 & 255.906 & 277,570 & 226,106 \\
\hline
\end{tabular}

\subsection{Liquidity Ratio}

\section{a. Current Ratio}

The current ratio shows the relationship between current assets and short-term liabilities of a company.

Table 2. Current Ratio of PT. Gresik Cipta Sejahtera Medan Branch

\begin{tabular}{cccc}
\hline Year & Short-term liabilities & Current assets & Current Ratio \\
\hline 2011 & $1,269,482$ & $4,062,287$ & 3.20 \\
2012 & $1,421,976$ & $4,584,704$ & 3.22 \\
2013 & 989,119 & $3,958,977$ & 4.00 \\
2014 & $2,439,590$ & $5,360,664$ & 2.20 \\
\hline
\end{tabular}

Table 2 shows that the ratio in 2011 was 3.20 . This means that the number of current assets is 3.20 times short-term liabilities, or every 1 rupiah of short-term liabilities is guaranteed by 3.20 rupiahs of current assets. In 2012 the value of the ratio increased to 3.22 and then 4.00 in 2013 which means the greater the guarantee of the company's short-term liabilities by current assets. In 2014 there was a decrease in the ratio to 2.20. The results of each ratio calculation show results > 2.00 which is a standard that is considered satisfactory for the growth of the company's financial performance as described on page 20.

\section{b. Fast Ratio}

This ratio is a quick test ratio that shows the company's ability to pay short-term liabilities with current assets without taking into account inventory.

Table 3. Rapid Ratio of PT. Gresik Cipta Sejahtera Medan Branch

\begin{tabular}{ccccc}
\hline Year & Short-term liabilities & Current assets & Stock & Fast Ratio \\
\hline 2011 & $1,269,482$ & $4,062,287$ & $1,802,707$ & 1.78 \\
2012 & $1,421,976$ & $4,584,704$ & $2,447,376$ & 1.50 \\
2013 & 989,119 & $3,958,977$ & $1,617,389$ & 2.37 \\
2014 & $2,439,590$ & $5,360,664$ & $2,461,256$ & 1.19 \\
\hline
\end{tabular}

Table 2 is known in 2011 amounted to 1.78 . And in 2012 there was a decrease in the value of the ratio to 1.50 . The value of the ratio in 2013 increased by 0.87 to 2.37 . The increase that occurred in 2013 could not be maintained in 2014, even the ratio reached its lowest value for 4 years, namely 1.19. If the industry average standard for the quick ratio is 2.0 , the growth of the company's financial performance can be said to be not good because in the last 3 years there are ratio values that are below the average, namely 2011, 2012, and 2013

\section{c. Cash ratio}


The cash ratio is a ratio to measure how much cash is available to pay debts.

Table 4. Cash Ratio of PT. Gresik Cipta Sejahtera Medan Branch

\begin{tabular}{cccc}
\hline Year & Short-term liabilities & Cash \& cash equivalents & Cash Ratio \\
\hline 2011 & $1,269,482$ & 841.121 & 0.66 \\
2012 & $1,421,976$ & 659,584 & 0.46 \\
2013 & 989,119 & 670,411 & 0.68 \\
2014 & $2,439,590$ & 613,698 & 0.25 \\
\hline
\end{tabular}

In 2011 the value of the ratio was 0.66 , this indicates that there is about $66 \%$ of cash available to pay short-term liabilities. In 2012 the value of the ratio fell to 0.46 . Then it rose again in 2013 to 0.68. In 2014 the ratio experienced a large decrease to 0.25 which indicates the company's minimum cash available to pay short-term liabilities. The result of the ratio in 2014 of 0.25 shows how the company was not able to maintain the value of the ratio they obtained from the previous year. If the industry's average cash ratio is 0.60 , the company's financial performance growth is in a bad position.

\subsection{Inventory to Net Working Capital}

This ratio is used to measure or compare the amount of existing inventory with the company's working capital.

Table 5. Inventory to Net Working Capital of PT. Gresik Cipta Sejahtera Medan Branch

\begin{tabular}{ccccc}
\hline Year & Stock & Current assets & Short-term liabilities & Inventory to NWC \\
\hline 2011 & $1,802,707$ & $4,062,287$ & $1,269,482$ & 0.65 \\
2012 & $2,447,376$ & $4,584,704$ & $1,421,976$ & 0.77 \\
2013 & $1,617,389$ & $3,958,977$ & 989,119 & 0.54 \\
2014 & $2,461,256$ & $5,360,664$ & $2,439,590$ & 0.84 \\
\hline
\end{tabular}

Table 5 shows that in 2011 the value of this ratio was 0.65 . In 2012 there was an increase in the value of the ratio to 0.77 . Meanwhile, in 2013 there was a decrease in the value of the ratio to 0.54 . The ratio rose again in 2014 there was an increase in the value of the ratio by 0.30 to 0.84 . If the industry average is 0.5 , the company's financial performance growth is in a good position. During 2011-2014, the company's liquidity ratio increased and decreased. These rights can be more easily seen through the graph. The graph depicting the liquidity ratio of PT. Gresik Cipta Sejahtera Medan Branch for 2011-2014, can be seen below.

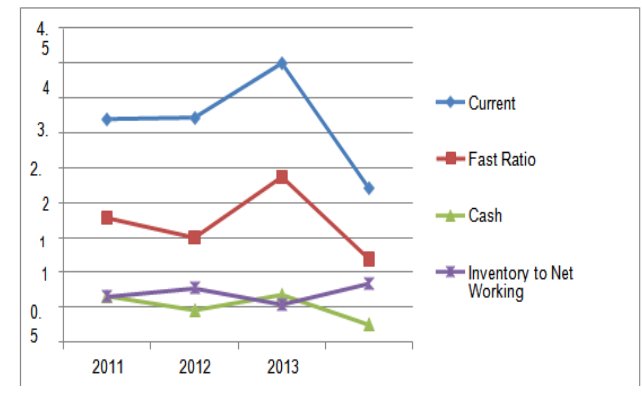

Figure 1. Liquidity of PT. Gresik Cipta Sejahtera Medan Branch

\subsection{Solvency Ratio}

a. Debt Ratio

Debt ratio is the ratio used to measure the ratio between total liabilities and total assets.

Table 6. Debt Ratio of PT. Gresik Cipta Sejahtera Medan Branch

\begin{tabular}{ccccc}
\hline Year & Asset & Liability & Debt Ratio & Debt Ratio (\%) \\
\hline
\end{tabular}




\begin{tabular}{lllll}
\hline 2011 & $5,881,108$ & $1,678,033$ & 0.2853 & $28.53 \%$ \\
2012 & $6,569,807$ & 1.972 .012 & 0.3002 & $30.02 \%$ \\
2013 & $6,130,320$ & 1.572 .120 & 0.2564 & $25.64 \%$ \\
2014 & $7,883,294$ & $2,991,184$ & 0.3794 & $37.94 \%$ \\
\hline
\end{tabular}

The results of the calculation of table 5 are known in 2011 the value of the ratio is $28.53 \%$. This ratio shows that $28.53 \%$ of the company's funding is financed with liabilities for 2011 . This means that every Rp. 100,00 corporate funding, Rp. 28.53 financed with liabilities and Rp. 71.47 provided by shareholders. The ratio rose to $30.02 \%$ in 2012 and then decreased by $4.38 \%$ in 2013 to $25.64 \%$. However, the ratio rose again to $37.94 \%$ in 2014 . When compared to the industry average of $30 \%$, the growth of the company's financial performance is considered less good. This means that the company is financed with liabilities exceeding the industry average.

\section{b. Debt to Equity Ratio}

Debt to equity ratio is the ratio that compares the company's liabilities to total equity.

Table 7. Debt to Equity Ratio of PT. Gresik Cipta Sejahtera Medan Branch

\begin{tabular}{ccccc}
\hline Year & Equity & Liability & Debt to Equity Ratio & Debt to Equity Ratio (\%) \\
\hline 2011 & $4,203,075$ & $1,678,033$ & 0.3992 & $39.92 \%$ \\
2012 & $4,597,795$ & 1.972 .012 & 0.4289 & $42.89 \%$ \\
2013 & $4,558,200$ & 1.572 .120 & 0.3449 & $34.49 \%$ \\
2014 & $4,892.110$ & $2,991,184$ & 0.6614 & $66.14 \%$ \\
\hline
\end{tabular}

The calculation in table 6 is known in 2011 at $39.92 \%$. This ratio shows that creditors provide Rp. 39.92 in 2011 for every Rp. 100.00 provided by shareholders. Or the company is financed by liabilities as much as $39.92 \%$. There was a change in the value of the ratio in 2012 to $42.89 \%$, an increase of $2.97 \%$, which means that the company's financing by liabilities increased by Rp. 2.97 . The ratio in 2013 fell to $34.49 \%$ and then rose again to $66.14 \%$ in 2014 . The ratio value in 2014 was the highest compared to the ratio in the last 3 years. If the industry average for debt to equity is $80 \%$, financial performance growth After doing the calculations, we can find out how the company's performance growth with solvency ratio during 2011-2014. To make it easier to see this, the following has shown the solvency ratio of PT. Gresik Cipta Sejahtera Medan Branch graphically.

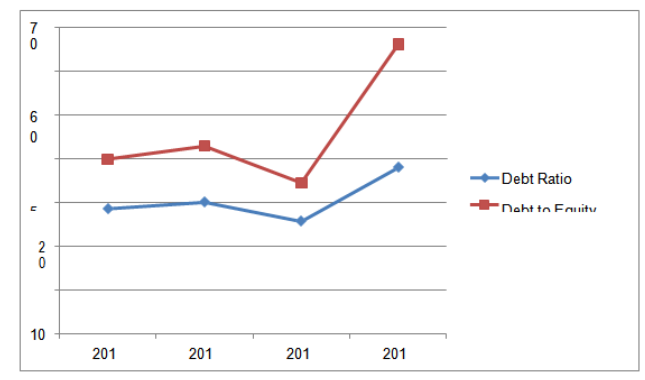

Figure 2. Solvency of PT. Gresik Cipta Sejahtera Medan Branch

\subsection{Profitability Ratio}

\section{a. Gross Profit Margin}

This ratio measures the efficiency of cost control

Table 8. Gross Profit Margin of PT. Gresik Cipta Sejahtera Medan Branch

\begin{tabular}{ccccc}
\hline Year & Sale & Gross profit & Gross profit margin & Gross profit margin (\%) \\
\hline 2011 & $8,339,254$ & $1,924,142$ & 0.2307 & $23.07 \%$ \\
2012 & 8.130 .051 & $1,883,427$ & 0.2317 & $23.17 \%$ \\
\hline
\end{tabular}




\begin{tabular}{|c|c|c|c|c|}
\hline 2013 & $7,363.168$ & $1,275,334$ & 0.1732 & $17.32 \%$ \\
\hline 2014 & $5,852,453$ & $1,443,721$ & 0.2467 & $24.67 \%$ \\
\hline
\end{tabular}

Table 8 shows that in 2011 it was $23.07 \%$ and in 2012 there was an increase in the value of the ratio to $23.17 \%$. This did not happen in 2013 where the ratio fell to $17.32 \%$. Meanwhile, in 2014 the ratio rose again to $24.67 \%$, exceeding the previous 3 years. If the industry average is $30 \%$, this result is considered less good for the company's financial performance because the company is not able to control inventory costs or the cost of producing goods.

b. Net Profit Margin

Net profit margin is a ratio used to measure net profit after tax compared to sales volume.

Table 9. Net Profit Margin of PT. Gresik Cipta Sejahtera Medan Branch

\begin{tabular}{ccccc}
\hline Year & Sale & Profit after interest \& tax & Net profit margin & Net profit margin (\%) \\
\hline 2011 & $8,339,254$ & 942.150 & 0.1130 & $11.30 \%$ \\
2012 & 8.130 .051 & 897.126 & 0.1103 & $11.03 \%$ \\
2013 & $7,363.168$ & 435,699 & 0.0592 & $5.57 \%$ \\
2014 & $5,852,453$ & 549,697 & 0.0939 & $9.39 \%$ \\
\hline
\end{tabular}

The results of the calculation of table 8 are known that in 2011 it was $11.30 \%$ and in 2012 there was a decrease in the ratio by $0.27 \%$ to $11.03 \%$. Likewise in 2013 where the ratio decreased to 5.57 . Meanwhile, in 2014 the value of the ratio rose to $9.39 \%$. If the industry average for net profit margin is $20 \%$, this condition is considered unfavorable for the company's financial performance because it is always below the industry average. This may be due to the company's relatively low prices of goods or relatively high costs or both.

\section{c. Return On Investment(ROI)}

ROI measures the company's ability to calculate the number of assets used in the company's operations to generate profits.

Table 10. Return On Investment PT. Gresik Cipta Sejahtera Medan Branch

\begin{tabular}{ccccc}
\hline Year & Asset & Profit after interest \& tax & Return On Investment & ROI (\%) \\
\hline 2011 & $5,881,108$ & 942.150 & 0.1602 & $16.02 \%$ \\
2012 & $6,569,807$ & 897.126 & 0.1366 & $13.66 \%$ \\
2013 & $6,130,320$ & 435,699 & 0.0711 & $7.11 \%$ \\
2014 & $7,883,294$ & 549,697 & 0.0697 & $6.97 \%$ \\
\hline
\end{tabular}

The calculation of ROI from table 9 shows that in 2011 the return on investment obtained was $16.02 \%$. Then in $2012-2014$ it fell to only $13.66 \%$, then $7.11 \%$, and finally $6.97 \%$. This means that in the span of 3 years the return on investment is reduced by $9.05 \%$ and this shows the inability of management to obtain ROI. If the industry average for $\mathrm{ROI}$ is $30 \%$, this result is not good for the company's financial performance because the ratio is below the industry average. The low ratio is due to low profit margins due to low asset turnover.

\section{d. Return On Equity(ROE)}

ROE is used to measure the company's rate of return in generating profits by utilizing the equity owned by the company.

Table 11. Return On Equity PT. Gresik Cipta Sejahtera Medan Branch

\begin{tabular}{|c|c|c|c|c|}
\hline Year & Equity & Profit after interest \& tax & Return On Equity & ROE (\%) \\
\hline 2011 & $4,203,075$ & 942.150 & 0.2242 & $22.42 \%$ \\
\hline 2012 & $4,597,795$ & 897.126 & 0.1951 & $19.51 \%$ \\
\hline 2013 & $4,558,200$ & 435,699 & 0.0956 & $9.56 \%$ \\
\hline 2014 & $4,892.110$ & 549,697 & 0.1124 & $11.24 \%$ \\
\hline
\end{tabular}


The calculation of ROE can be seen through table10, it is known that in 2011 the return on equity obtained was $22.41 \%$. Then, in 2012 and 2013 it fell to only $19.51 \%$ and then $9.56 \%$. This means that the return on equity until 2013 was reduced by $12.86 \%$ and this indicates the management's inability to obtain ROE along with the decline in ROI. In 2014 the company was finally able to make an increase by obtaining a ratio of $11.24 \%$. If the industry average for ROE is $40 \%$, the company's financial performance growth is not good because it is always below the industry average. Results like this mean that the company cannot demonstrate the efficient use of its own capital From the results of the above calculations, we can see how the company during 2011-2014 made efforts to obtain maximum profit or profit. The results of these calculations can be seen graphically on the next page so that it can be easier to know the growth of company performance with profitability ratios.

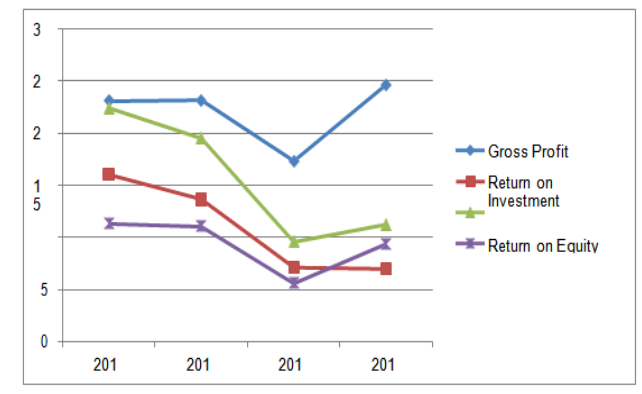

Figure 3. Profitability of PT. Gresik Cipta Sejahtera Medan Branch

\section{CONCLUSION}

The results of the measurement of the current ratio and Inventory to net working capital show good growth in financial performance, where the current ratio from 2011-2014 is $>2$, meaning that shortterm liabilities are guaranteed by $\mathrm{Rp} .2 .00$, and Inventory to net working capital is above the industry average and the ratio value is also close to 1.00 .

The results of quick ratios and cash ratios from 2011-2014 show poor growth in financial performance because the company's ratios are still below the industry average.

debt ratio the years 2011-2014 showed a growth in the company's financial performance that was not good because the company was financed by debt exceeding the industry average.

Debt to equity ratio 2011-2014 showed good growth in the company's financial performance because the ratio value was always below the industry average.

From the analysis of gross profit margin, net profit margin, ROI, and ROE for the years 20112014, the growth of the company's financial performance is in a bad position because the ratio value is below the industry average.

\section{REFERENCES}

Baridwan, Zaki. 2014. Intermediate Accounting. BPFE-YOGYAKARTA. Yogyakarta.

Fahmi, Irham. 2012. Analisis Kinerja Keuangan. Alfabeta. Bandung. 2012. Manajemen Keuangan. Alfabeta. Bandung.

Fraser, Lyn M. dan Aileen Ormiston. 2008. Memahami Laporan Keuangan. Indeks. Jakarta

Harahap, Sofyan Syafri. 2008. Analisis Kritis atas Laporan Keuangan. PT. Raja Grafindo Persada. Jakarta

Harmono, DR. 2009. Manajemen Keuangan Berbasis Balanced Scorecard Pendekatan Teori, Kasus, dan Riset Bisnis. Bumi Aksara. Jakarta.

Ikatan Akuntan Indonesia. 2009. Standar Akuntansi Keuangan. Salemba Empat. Jakarta.

Juliandi, Azwar dan Irfan. 2013. Metodologi Penelitian Kuantitatif untuk IImu- ilmu Bisnis. Citapustaka Media Perintis. Bandung

Kasmir. 2010. Pengantar Manajeman Keuangan. Kencana. Jakarta. 2012. Analisis Laporan Keuangan. PT. Rajagrafindo Persada. Jakarta. 
Kaunang, James Marcel. 2012. Analisis Laporan Arus Kas sebagai Alat Ukur Menilai Kinerja pada PT. Pegadaian (Persero) Cabang Manado Timur. Skripsi. Universitas Sam Ratulangi. Manado.

Kotandengan, Ben. 2012. Analisis Kinerja Keuangan Perusahaan Ditinjau dari Rentabilitas, Likuiditas dan Solvabilitas pada PT. Setia Tri Jujur Bersama. Skripsi. Universitas Sam Ratulangi. Manado.

Lukviarman, Nikki. 2006. Dasar-Dasar Manajemen Keuangan. Andalas University Press. Padang.

Manurung, Risa Purnama. 2013. Analisis Laporan Keuangan Sebagai Dasar Penilaian Kinerja Keuangan Perusahaan Pada PT. Unilever Indonesia, Tbk. Skripsi. Universitas Sumatera Utara. Medan.

Orniati, Yuli. 2008. Laporan Keuangan sebagai Alat untuk Menilai Kinerja Keuangan PT. Wira Jatim Group Pabrik Es Betek. Skripsi. Universitas Gajayana. Malang.

Pongoh, Marsel. 2012. Analisis Laporan Keuangan untuk Menilai Kinerja Keuangan PT. Bumi Resources Tbk. Skripsi. Universitas Sam Ratulangi. Manado.

Praytino, Ryanto Hadi. 2010. Peranan Analisa Laporan Keuangan dalam Mengukur Kinerja Keuangan Perusahaan: Studi Kasus pada PT. X. Jurnal Manajemen Volume 2 No. 1. UNNUR. Bandung.

Skousen, K. Fred, Earl K. Stice dan James D. Stice. 2001. Akuntansi Keuangan Menengah. PT Dian Mas Cemerlang. Jakarta.

Raharjaputra, Hendra S. 2011. Manajemen Keuangan dan Akuntansi. Salemba Empat. Jakarta.

Wahyudin, Moh. 2008. Manajemen Keuangan Perusahaan. BPFE. Yogyakarta. 